\title{
PERFORMANCE OF SESAME(Sesamumindicum L.) VARIETIES UNDER VARIED NUTRIENT LEVELS
}

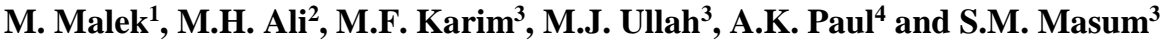 \\ ${ }^{1}$ Farm Management Wing, ${ }^{3}$ Department of Agronomy, ${ }^{4}$ Department of Soil Science, \\ Sher-e-Bangla Agricultural University, ${ }^{2}$ Fast Capital University of Bangladesh \\ Corresponding E-mail: smmasum607@ sau.edu.bd
}

(Received: 01 August 2021, Accepted: 27 September 2021)

Keywords: Sesame, nutrient levels, varieties, high yield, Bangladesh

\begin{abstract}
The study was carried out to evaluate some sesame varieties under different nutrient levels for enhancing the productivity of sesame during March - June, 2014. The experiment was carried out in a split-plot design with three replications. The main -plot treatments had four nutrient levels viz., $75 \%$ of the recommended dose of fertilizer(RDF), $100 \%$ RDF, $125 \%$ of RDF, and $150 \%$ of RDF, and the sub - plot treatments included six sesame varieties viz., Laltil (Local), Atshira (Local), $\mathrm{T}_{6}$, BARI Til-3, BARI Til-4 and Binatil-2. RDF indicates a nutrient schedule of 56:72:23 $\mathrm{kg} \mathrm{N}, \mathrm{P}_{2} \mathrm{O}_{5}$, and $\mathrm{K}_{2} \mathrm{O} \mathrm{ha}^{-1}$. The effect of nutrient levels, varieties, and their interaction showed significant variation in respect of yield contributing parameters, yield, and harvest index. Results revealed that in nutrient levels, $100 \%$ of RDF produced the highest seed yield $\left(1223 \mathrm{~kg} \mathrm{ha}^{-1}\right)$. The least seed yield was observed with $150 \%$ of $\mathrm{RDF}\left(924 \mathrm{~kg} \mathrm{ha}^{-1}\right)$. Among the sesame varieties,BARI Til-4 showed the optimum growth and yield contributing parameters as a result highest seed yield $\left(1170 \mathrm{~kg} \mathrm{ha}^{-1}\right)$. The lowest seed yield was obtained from Laltil $\left(811.30 \mathrm{~kg} \mathrm{ha}^{-1}\right)$. The interaction effect was found significant where highest seed yield of $1481 \mathrm{~kg} \mathrm{ha}^{-1}$ with $100 \%$ of RDF combination of sesame var. BARI Til-4.
\end{abstract}

\section{Introduction}

Sesame (Sesamumindicum L.) commonly known as til in Bengali, belongs to the Sesamum genus of the Pedaliaceae family. It is grown mainly for seeds that contain $46 \%-64 \%$ oil and $20 \%$ protein (Raja $e t$ al., 2007). Sesame oil contains good quality poly-unsaturated fatty acids viz., $47 \%$ oleic and $39 \%$ linoleic acid.

The crop is cultivated either as a pure stand or as a mixed crop with aus rice, jute, groundnut, millets, and sugarcane. In Bangladesh, sesame occupies a remarkable area under production and contributes second-ranked production after rapeseed and mustard. Although at present about 3, 21,338hectares of land are under sesame cultivation with a production of 19795 metric tons (BBS, 2020) but land area and production under sesame cultivation is decreasing day by day. In 2009-10, about 36 thousand hectares of land were under sesame cultivation where total production was 32306 metric tons (BBS, 2010). However, the climatic and edaphic conditions of Bangladesh are quite suitable for the cultivation ofsesame. Khulna, Jashore, Faridpur, Barisal, Patuakhali, Rajshahi, Pabna, Rangpur, Sylhet, Cumilla, Dhaka, and Mymensingh districts are the leading sesame producing areas of Bangladesh.

Lack of acclimatizing high yielding varieties, poor crop stand establishment, capsule shattering, uneven ripening, lesser fertilizer retorts, abundant branching, indeterminate growth habit, truncated harvest index, and vulnerability to diseases are the restrictivereasons in sesame production worldwide (Tripathy et al., 2019). However, the environmental conditions, agricultural operations such as nutrition, and varieties have an impacton sesame seed yield and its harvest index (Bedigian et al., 1985). This probably indicates a great opportunity for a prolonged and higher increase in the 
productivity of sesame. To increase the productivity of sesame, various improved technologies are needed and among them, various agro-techniques, isolating location-specific varieties assumes greater significance (Myint et al., 2020). In particular, variety, sowing time, population density and/or plant spacing, and fertilizermanagement in the soil play significant roles as determinants of seed yield. There are several modern varieties available in Bangladesh; but, the farmers are continuing to grow local varieties. Besides, inappropriate use of fertilizers is one of the major production constraints. Therefore, adoption of sustainable variety and maintenance of nutrient status in the soil would fulfill the maximizing yield of sesame (Monayem et al., 2015). Higher productivity in any crop can be achieved through a combination of ideal variety associated with appropriate nutrient management practices.Besides, without or little use of fertilizers for sesame is a common practice in in Bangladesh. Keeping all the above facts, the study was undertaken to comparethe varietiesalong with the fertilizer management on sesame growth performance and productivity.

\section{Materials and Methods}

The experiment was carried out at the research field of the Agronomy Department, Sher-e-Bangla Agricultural University, Dhaka during March-June 2014. The experimental field was located at $90^{\circ} 33^{\prime}$ E longitude and $23^{\circ} 71^{\prime} \mathrm{N}$ latitude at a height of $9 \mathrm{~m}$ above the sea level. The climate of the experimental area was sub-tropical and characterized by high temperature, heavy rainfall during Kharif-1 season (March-June), and scanty rainfall during Rabi season (October-March) associated with moderately low temperature (Khanam et al., 2016). The land belongs to the Agro-ecological zone "Madhupur tract" (AEZ-28) having the Red Brown Trace Soils of Tejgaon series. The soil of the experimental site was well-drained and medium-high. The physical and chemical properties of the soil of the experimental site are silty clay in texture and having soil $\mathrm{pH}$ varied from 5.45-5.61. Organic matter content was very low (0.83). The soil physical components such as sand, silt, clay content were $26 \%, 45 \%$, and $29 \%$, respectively, organic carbon 0.45 , total N $0.61 \%, \mathrm{~K}_{0.11}$ meq $100 \mathrm{~g}$ soil ${ }^{-1}$, and $\mathrm{P}, \mathrm{S}, \mathrm{B}$, and $\mathrm{Zn} 0.65,7.74,0.35$ and $3.99 \mu \mathrm{gg}^{-1} \mathrm{ppm}$, respectively. The experiment consisted of split-plot design where nutrient levels was placed in main - plot and variety in sub- plot (Table 1). Laltil variety was collected from Ullapara, Sirajgonj where Atshira variety from Khoksha, Kushtia, and rest varieties. $\mathrm{T}_{6}$, (BARI Til-3, and BARI Til-4) from Bangladesh Agricultural Research Institute (BARI), Joydeppur, Gazipur. The variety Binatil 2 was collected from the Bangladesh Institute of Nuclear Agriculture (BINA). The treatments in main -plot were nutrient levels viz.

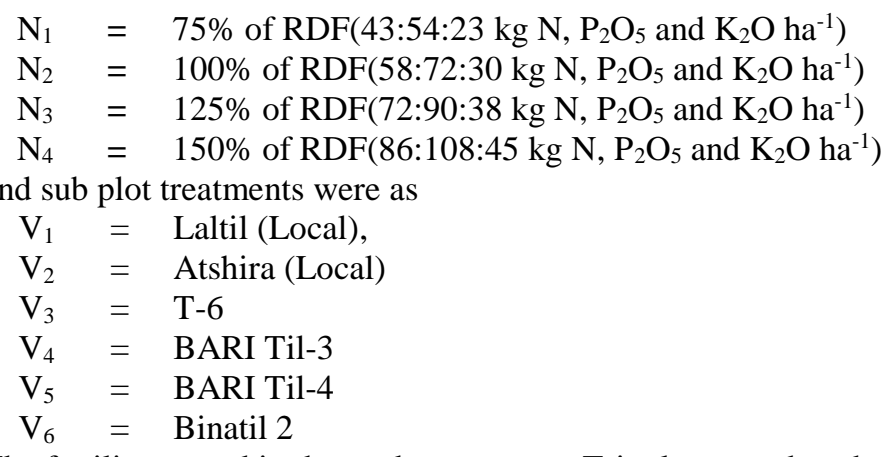

The fertilizers used in the study were urea, Tripple superphosphate (TSP), and Muriate of potash (MoP) to supply N, P, and K, respectively (FRG, BARC, 2012). Before sowing seeds, the percentage of germination was found over 95 . Row spacing was $30 \mathrm{~cm}$ with seed rate $5 \mathrm{Kg} / \mathrm{ha}$. Seeds were placed 2$3 \mathrm{~cm}$ depth in rows and seeds were covered with loose soil properly. The thinning operation was done for ensuring the optimum plant populations. All other recommended agronomic practices were followed (BARI, 2013). Regular observations were made to observe the growth stages of the crop. The data collected on different parameters were statistically analyzed by using the MSTATC computer 
package program and treatment means were compared by LSD test at 5\% level of probability (Gomez and Gomez, 1984).

\section{Results and Discussion}

\section{Effect of nutrient levels on yield attributes}

A significant variation was observed for the number of capsule plant ${ }^{-1}$, number of seeds capsule ${ }^{-1}$, capsule length, and weight of 1000- seedsdue to the application of different nutrient levels on sesame (Table 2). Regarding nutrient levels, the number of capsules plant ${ }^{-1}$ was maximum (77.28) from $100 \%$ of RDF $\left(\mathrm{N}_{2}\right)$ followed by $\mathrm{N}_{3}$ (125\% of RDF). loweR number of capsule plant ${ }^{-1}$ (63.83) was recorded from $75 \%$ of RDF $\left(\mathrm{N}_{1}\right)$ which was statistically similar with $\mathrm{N}_{4}$ (150\% of RDF). Bennet et al. (1996) also found an increased number of capsules plant ${ }^{-1}$ with Napplication up to $120 \mathrm{~kg} \mathrm{ha}^{-1}$. Each successive increase in the dose of $\mathrm{N}$ up to $60 \mathrm{~kg} \mathrm{ha}^{-1}$ significantly increased the capsules plant ${ }^{-1}$ (Prakash et al., 2001). Nahar et al. (2008) indicated that the number of capsules plant $^{-1}$ increased significantly up to $100 \mathrm{~kg} \mathrm{~N}^{-1}$. Significantly higher seed yield was recorded with $50 \mathrm{~kg} \mathrm{P}_{2} \mathrm{O}_{5} \mathrm{ha}^{-1} \mathrm{due}$ to an increase in capsules plant ${ }^{-1}$ (Prakasha and Thimmegowda, 1992). Mian et al. (2011) opined that the highest number of capsules plant ${ }^{-1}$ was recorded with $90 \mathrm{~kg} \mathrm{P}_{2} \mathrm{O}_{5} \mathrm{ha}^{-1}$. Increasing the level of $\mathrm{K}$ from 100 to 150 percent of the recommended dose, the number of capsules plant ${ }^{-1}$ of Sesamum increased significantly (Subrahmaniyan et al., 2001).The number of seeds capsule ${ }^{-1}$ was maximum (79.53) from $100 \%$ of RDF $\left(\mathrm{N}_{2}\right)$ followed by $\mathrm{N}_{3}$ (125\% of RDF). The lowest number of seeds capsule ${ }^{-1}$ (72.76) was recorded from $150 \%$ of RDF $\left(\mathrm{N}_{4}\right)$ which was statistically similar with $\mathrm{N}_{1}(125 \%$ of $\mathrm{RDF}$ ). Nahar et al. (2008) also indicated that the seeds capsule $\mathrm{e}^{-1}$ increased significantly up to $100 \mathrm{~kg} \mathrm{~N} \mathrm{ha}^{-1}$. Kathiresan (1999) indicated that the P level of $35 \mathrm{~kg} \mathrm{ha}^{-1}$ influenced the number of seeds capsule ${ }^{-1}$ of Sesamum. Application of potassium markedly increased the number of seeds capsule ${ }^{-1}$ (Mandal et al., 1992). Tiwari et al. (1994) was found that the application of $\mathrm{K}_{2} \mathrm{O}$ significantly increased the seeds capsule $^{-1}$ of Sesamum. The capsule length was maximum $(3.19 \mathrm{~cm})$ from $100 \%$ of RDF $\left(\mathrm{N}_{2}\right)$ followed by $\mathrm{N}_{3}\left(125 \%\right.$ of RDF). The lowest capsule length $(2.13 \mathrm{~cm})$ was recorded from $150 \%$ of RDF $\left(\mathrm{N}_{4}\right)$ which was statistically similar with $\mathrm{N}_{1}$ (75\% of RDF). Mian et al. (2011) opined that the highest capsule length was recorded with $90 \mathrm{~kg} \mathrm{P}_{2} \mathrm{O}_{5} \mathrm{ha}^{-1}$ compared to 70 and $110 \mathrm{~kg} \mathrm{P}_{2} \mathrm{O}_{5} \mathrm{ha}^{-1}$. Tiwari et al. (1994) was found that the application of $\mathrm{K}_{2} \mathrm{O}$ significantly increased the capsule length of sesame. The weight of 1000 -- seeds was highest $\left(2.78 \mathrm{~g}\right.$ ) from $100 \%$ of RDF $\left(\mathrm{N}_{2}\right)$ followed by $\mathrm{N}_{3}(125 \%$ of RDF). The lowest weight of 1000 - seeds $(2.60 \mathrm{~g})$ was recorded from $75 \%$ of RDF $\left(\mathrm{N}_{1}\right)$ which was statistically similar with $\mathrm{N}_{4}$ (150\% of RDF). Ghosh and Patra (1994) recorded a higher 1000 -seeds weight of Sesamum upto $60 \mathrm{~kg} \mathrm{~N} \mathrm{ha}^{-1}$. Each successive increase in the dose of $\mathrm{N}$ up to $60 \mathrm{~kg} \mathrm{ha}^{-1}$ significantly increased 1000 -seeds weight (Prakash et al., 2001). Nahar et al. (2008) indicated that the 1000- seeds weight increased significantly up to $100 \mathrm{~kg} \mathrm{~N} \mathrm{ha}^{-1}$. Mian et al. (2011) opined that the highest 1000 seeds weight was recorded with $90 \mathrm{~kg} \mathrm{P}_{2} \mathrm{O}_{5} \mathrm{ha}^{-1}$. Application of potassium markedly increased the 1000- seeds weight (Mandal et al., 1992). Prakasha and Thimmegowda (1992) reported 53 percent increased seed yield with higher $\mathrm{N}$ rate due to enhanced value of yield attributes viz., capsules plant ${ }^{-1}$, number of seeds capsule ${ }^{-1}$, capsule length, and weight of 1000 -seeds.

\section{Performance of varieties in terms of yield attributes}

The tested local and modern varieties of sesame varied significantly in number of capsule plant ${ }^{-1}$, number of seeds capsule ${ }^{-1}$, capsule length, and weight of 1000- seeds (Table 2). The maximum number of capsule plant ${ }^{-1}$ (77.33) was obtained from $\mathrm{V}_{5}$ (BARI Til-4) followed by $\mathrm{V}_{4}$ (BARI Til-3).

Table 2. Effect of nutrient levels, variety, and their interaction on yield contributing parameters of sesame

\begin{tabular}{ccccc}
\hline Treatment & \multicolumn{3}{c}{ Yield contributing parameters } \\
\cline { 2 - 5 } & $\begin{array}{c}\text { Number of capsule } \\
\text { plant }^{-1}\end{array}$ & $\begin{array}{c}\text { Number of seeds } \\
\text { capsule }^{-1}\end{array}$ & $\begin{array}{c}1000 \text {-seeds } \\
\text { weight }(\mathrm{g})\end{array}$ & $\begin{array}{c}\text { Capsule length } \\
(\mathrm{cm})\end{array}$ \\
\hline
\end{tabular}

Nutrient levels 


\begin{tabular}{|c|c|c|c|c|}
\hline $\mathrm{N}_{1}$ & $63.83 \mathrm{c}$ & $73.05 \mathrm{c}$ & $2.60 \mathrm{c}$ & $2.18 b c$ \\
\hline $\mathrm{N}_{2}$ & $77.28 \mathrm{a}$ & $79.53 \mathrm{a}$ & $2.78 \mathrm{a}$ & $2.32 \mathrm{a}$ \\
\hline $\mathrm{N}_{3}$ & $69.11 \mathrm{~b}$ & $75.69 \mathrm{~b}$ & $2.70 \mathrm{~b}$ & $2.24 b$ \\
\hline $\mathrm{N}_{4}$ & $64.28 \mathrm{c}$ & $72.76 \mathrm{c}$ & $2.62 \mathrm{c}$ & $2.13 \mathrm{c}$ \\
\hline $\mathrm{LSD}_{0.05}$ & 1.21 & 1.41 & 0.04 & 0.06 \\
\hline \multicolumn{5}{|l|}{ Varieties } \\
\hline $\mathrm{V}_{1}$ & $56.58 \mathrm{f}$ & $65.82 \mathrm{e}$ & $2.45 \mathrm{c}$ & $2.05 \mathrm{c}$ \\
\hline $\mathrm{V}_{2}$ & $59.17 \mathrm{e}$ & $69.03 \mathrm{~d}$ & $2.52 \mathrm{c}$ & $2.12 \mathrm{~b}$ \\
\hline $\mathrm{V}_{3}$ & $70.25 \mathrm{~d}$ & $77.66 \mathrm{c}$ & $2.73 \mathrm{~b}$ & $2.26 \mathrm{a}$ \\
\hline $\mathrm{V}_{4}$ & $76.08 \mathrm{~b}$ & $79.67 \mathrm{~b}$ & $2.79 \mathrm{ab}$ & $2.30 \mathrm{a}$ \\
\hline $\mathrm{V}_{5}$ & $77.33 \mathrm{a}$ & $80.76 \mathrm{a}$ & $2.81 \mathrm{a}$ & $2.31 \mathrm{a}$ \\
\hline $\mathrm{V}_{6}$ & $72.33 \mathrm{c}$ & $78.62 \mathrm{c}$ & $2.75 \mathrm{ab}$ & $2.28 \mathrm{a}$ \\
\hline $\mathrm{LSD}_{0.05}$ & 0.93 & 0.97 & 0.07 & 0.05 \\
\hline \multicolumn{5}{|c|}{ Combination of nutrient levels and varieties } \\
\hline $\mathrm{N}_{1} \mathrm{~V}_{1}$ & $58.67 \mathrm{jk}$ & 68.30hij & $2.47 \mathrm{~h}$ & $2.15 \mathrm{ghi}$ \\
\hline $\mathrm{N}_{1} \mathrm{~V}_{2}$ & $63.67 \mathrm{hi}$ & $72.77 \mathrm{~g}$ & $2.60 \mathrm{fg}$ & $2.17 \mathrm{gh}$ \\
\hline $\mathrm{N}_{1} \mathrm{~V}_{3}$ & $64.67 \mathrm{ghi}$ & $72.90 \mathrm{~g}$ & $2.63 \mathrm{fg}$ & $2.17 \mathrm{gh}$ \\
\hline $\mathrm{N}_{1} \mathrm{~V}_{4}$ & $65.00 \mathrm{gh}$ & $75.57 \mathrm{fg}$ & $2.63 \mathrm{fg}$ & $2.20 \mathrm{fg}$ \\
\hline $\mathrm{N}_{1} \mathrm{~V}_{5}$ & $66.33 \mathrm{fgh}$ & $75.80 \mathrm{fg}$ & $2.63 \mathrm{fg}$ & $2.23 \mathrm{ef}$ \\
\hline $\mathrm{N}_{1} \mathrm{~V}_{6}$ & $64.67 \mathrm{ghi}$ & $72.97 \mathrm{~g}$ & $2.63 \mathrm{efg}$ & $2.20 f g$ \\
\hline $\mathrm{N}_{2} \mathrm{~V}_{1}$ & $56.33 \mathrm{kl}$ & $67.47 \mathrm{hij}$ & $2.47 \mathrm{~h}$ & $2.13 \mathrm{hi}$ \\
\hline $\mathrm{N}_{2} \mathrm{~V}_{2}$ & $61.67 \mathrm{ij}$ & $69.43 \mathrm{~h}$ & $2.53 \mathrm{gh}$ & $2.16 \mathrm{gh}$ \\
\hline $\mathrm{N}_{2} \mathrm{~V}_{3}$ & $76.67 \mathrm{c}$ & $82.33 b c$ & $2.87 \mathrm{~b}$ & $2.36 b c$ \\
\hline $\mathrm{N}_{2} \mathrm{~V}_{4}$ & $93.00 \mathrm{a}$ & $85.33 \mathrm{ab}$ & $2.97 \mathrm{a}$ & $2.42 \mathrm{a}$ \\
\hline $\mathrm{N}_{2} \mathrm{~V}_{5}$ & $94.67 \mathrm{a}$ & $88.13 \mathrm{a}$ & $3.00 \mathrm{a}$ & $2.43 \mathrm{a}$ \\
\hline $\mathrm{N}_{2} \mathrm{~V}_{6}$ & $81.33 \mathrm{~b}$ & $84.50 \mathrm{~b}$ & $2.87 \mathrm{~b}$ & $2.41 \mathrm{ab}$ \\
\hline $\mathrm{N}_{3} \mathrm{~V}_{1}$ & $56.00 \mathrm{kl}$ & $65.97 \mathrm{ij}$ & $2.43 \mathrm{~h}$ & $2.10 \mathrm{i}$ \\
\hline $\mathrm{N}_{3} \mathrm{~V}_{2}$ & $59.67 \mathrm{j}$ & $68.77 \mathrm{hi}$ & $2.50 \mathrm{~h}$ & $2.15 \mathrm{ghi}$ \\
\hline $\mathrm{N}_{3} \mathrm{~V}_{3}$ & $72.00 \mathrm{~d}$ & 78.40def & $2.80 \mathrm{bc}$ & $2.27 \mathrm{e}$ \\
\hline $\mathrm{N}_{3} \mathrm{~V}_{4}$ & $75.33 \mathrm{c}$ & $80.10 \mathrm{cde}$ & $2.83 \mathrm{bc}$ & $2.32 \mathrm{~cd}$ \\
\hline $\mathrm{N}_{3} \mathrm{~V}_{5}$ & $76.67 \mathrm{c}$ & $81.20 \mathrm{~cd}$ & $2.83 \mathrm{bc}$ & $2.35 \mathrm{c}$ \\
\hline $\mathrm{N}_{3} \mathrm{~V}_{6}$ & $75.00 \mathrm{c}$ & $79.70 \mathrm{~cd}$ & $2.80 \mathrm{bc}$ & $2.28 \mathrm{de}$ \\
\hline $\mathrm{N}_{4} \mathrm{~V}_{1}$ & 55.331 & $61.53 \mathrm{k}$ & $2.43 \mathrm{~h}$ & $1.82 \mathrm{k}$ \\
\hline $\mathrm{N}_{4} \mathrm{~V}_{2}$ & $51.67 \mathrm{~m}$ & $65.17 \mathrm{j}$ & $2.43 \mathrm{~h}$ & $2.02 \mathrm{j}$ \\
\hline $\mathrm{N}_{4} \mathrm{~V}_{3}$ & $67.67 \mathrm{fg}$ & 77.00ef & $2.63 \mathrm{efg}$ & $2.23 \mathrm{ef}$ \\
\hline $\mathrm{N}_{4} \mathrm{~V}_{4}$ & $71.00 \mathrm{de}$ & 77.67ef & $2.73 \mathrm{cde}$ & $2.24 \mathrm{ef}$ \\
\hline $\mathrm{N}_{4} \mathrm{~V}_{5}$ & $71.67 \mathrm{~d}$ & 77.90def & $2.77 \mathrm{bcd}$ & $2.24 \mathrm{ef}$ \\
\hline $\mathrm{N}_{4} \mathrm{~V}_{6}$ & $68.33 \mathrm{ef}$ & 77.30ef & $2.70 \mathrm{def}$ & $2.24 \mathrm{ef}$ \\
\hline $\mathrm{LSD}_{0.05}$ & 2.975 & 3.026 & 0.090 & 0.052 \\
\hline
\end{tabular}

In a column means having similar letter(s) are statistically similar and those having dissimilar letter(s) differ significantly at 0.05 level of probability.

Note: $\mathrm{N}_{1}=75 \%$ of RDF (43:54:23 kg N, P2O5 and K2O ha $\left.{ }^{-1}\right), \mathrm{N}_{2}=100 \%$ of RDF (58:72:30 kg N, P2O5 and K2O ha-1), $\mathrm{N}_{3}=125 \%$ of $\operatorname{RDF}\left(72: 90: 38 \mathrm{~kg} \mathrm{~N}, \mathrm{P}_{2} \mathrm{O}_{5}\right.$ and $\left.\mathrm{K}_{2} \mathrm{O} \mathrm{ha}^{-1}\right), \mathrm{N}_{4}=150 \%$ of RDF (86:108:45 kg N, $\mathrm{P}_{2} \mathrm{O}_{5}$ and $\left.\mathrm{K}_{2} \mathrm{O} \mathrm{ha}^{-1}\right) ; \mathrm{V}_{1}=$ Laltil (Local), $\mathrm{V}_{2}=$ Atshira (Local), $\mathrm{V}_{3}=\mathrm{T}-6, \mathrm{~V} 4=$ BARI Til-3, $\mathrm{V}_{5}=$ BARI Til-4, $\mathrm{V}_{6}=$ Binatil 2

The lowest number of capsule plant ${ }^{-1}$ (56.58) was observed from local variety $\mathrm{V}_{1}$ (Laltil) followed by local variety $\mathrm{V}_{2}$ (Atshira). El-Serogy et al. (1997), Deshmukh et al. (2005), Kokilavani et al. (2007), and Riaz et al. (2002) indicated that the number of capsules plant ${ }^{-1}$ differed significantly by different varieties. The maximum number of seeds capsule ${ }^{-1}$ (80.76) was obtained from $\mathrm{V}_{5}$ (BARI Til-4) followed by $\mathrm{V}_{4}$ (BARI Til-3). The lowest number of seeds capsule ${ }^{-1}$ (65.82) was observed from local variety $\mathrm{V}_{1}$ (Laltil) followed by local variety $\mathrm{V}_{2}$ (Atshira). Variation in the number of seeds capsule ${ }^{-1}$ was noticed significantly among varieties (Govindaraju and Balakrishnan, 2002). Ali and Jan (2014) and Chongdar et al. (2015) also observed variation in the number of seeds capsule ${ }^{-1}$ due to different varietal performance The maximum capsule length $\left(2.31 \mathrm{~cm}\right.$ ) was obtained from $\mathrm{V}_{5}$ (BARI Til-4) 
which was statistically similar with $\mathrm{V}_{3}$ (T-6), $\mathrm{V}_{4}$ (BARI Til-3), and $\mathrm{V}_{6}$ (Binatil 2). The lowest capsule length $(2.05 \mathrm{~cm})$ was observed from local variety $\mathrm{V}_{1}$ (Laltil) followed by local variety $\mathrm{V}_{2}$ (Atshira). Riaz et al. (2002) and Lakshmi and Lakshmamma (2005) also found similar results regarding capsule length of sesame and observed that different varieties showed different capsule lengths.

The maximum weight of 1000- seeds $(2.81 \mathrm{~g})$ was obtained from $\mathrm{V}_{5}$ (BARI Til-4) which was statistically similar to $\mathrm{V}_{4}$ (BARI Til-3) and $\mathrm{V}_{6}$ (Binatil 2). The lowest weight of 1000 -seeds $(2.45 \mathrm{~g}$ ) was observed from local variety $\mathrm{V}_{2}$ (Atshira) which was statistically similar with local variety $\mathrm{V}_{1}$ (Laltil). Similar results on 1000- seeds weight was found from Rao et al. (1990) and Yadav et al. (1991) which supported the present findings. They observed that the HYV variety gave a higher 1000seed weight than the local variety.

\section{Interaction effect of nutrient levels and varieties on yield attributes}

Results showed that yield attributes due to the combination between different nutrient levels and varieties were significant (Table 2). The combination of $\mathrm{N}_{2} \mathrm{~V}_{5}$ showed the maximum number of capsule plant ${ }^{-1}$ (94.67) which was statistically similar with $\mathrm{N}_{2} \mathrm{~V}_{4}$ followed by $\mathrm{N}_{2} \mathrm{~V}_{6}$. The lowest number of capsule plant ${ }^{-1}$ was recorded from $\mathrm{N}_{4} \mathrm{~V}_{1}$ (55.33) which were statistically similar with $\mathrm{N}_{3} \mathrm{~V}_{1}$ and $\mathrm{N}_{2} \mathrm{~V}_{1}$. The maximum number of seeds capsule ${ }^{-1}(88.13)$ from the $\mathrm{N}_{2} \mathrm{~V}_{5}$ combination was statistically similar with $\mathrm{N}_{2} \mathrm{~V}_{4}$ followed by $\mathrm{N}_{2} \mathrm{~V}_{6}$. The lowest number of seeds capsule ${ }^{-1}$ was recorded from $\mathrm{N}_{4} \mathrm{~V}_{1}(61.53)$ followed by $\mathrm{N}_{4} \mathrm{~V}_{2}$ and $\mathrm{N}_{3} \mathrm{~V}_{1}$. The maximum capsule length $(2.43 \mathrm{~cm})$ was recorded from $\mathrm{N}_{2} \mathrm{~V}_{5}$ which was statistically similar with $\mathrm{N}_{2} \mathrm{~V}_{4}$ and closely followed by $\mathrm{N}_{2} \mathrm{~V}_{6}$. The lowest capsule lengthwas recorded from $\mathrm{N}_{4} \mathrm{~V}_{1}(1.82 \mathrm{~cm})$ followed by $\mathrm{N}_{4} \mathrm{~V}_{2}$. Different varieties had a significant response to different nutrient rates. Similarly, the variety T6 and BARI Til-3 showed increased capsule length up to $100 \mathrm{~kg} \mathrm{~N} \mathrm{ha}^{-1}$ but the variety BARI Til 2 responded up to $150 \mathrm{~kg} \mathrm{~N} \mathrm{ha}^{-1}$ (Nahar et al., 2008). The maximum weight of 1000- seeds ( $3.00 \mathrm{~g}$ ) was obtained from the $\mathrm{N}_{2} \mathrm{~V}_{5}$ which was statistically similar with $\mathrm{N}_{2} \mathrm{~V}_{4}$ followed by $\mathrm{N}_{2} \mathrm{~V}_{3}$ and $\mathrm{N}_{2} \mathrm{~V}_{6}$. The lowest weight of 1000- seeds was recorded from $\mathrm{N}_{4} \mathrm{~V}_{1}$ (2.47 g) which were statistically similar with $\mathrm{N}_{2} \mathrm{~V}_{1}, \mathrm{~N}_{3} \mathrm{~V}_{1}, \mathrm{~N}_{3} \mathrm{~V}_{2}, \mathrm{~N}_{4} \mathrm{~V}_{1}$ and $\mathrm{N}_{4} \mathrm{~V}_{2}$.

\section{Effect of nutrient levels on yield and harvest index}

Seed yield, stover yield, and harvest index were significantly influenced due to different nutrient levels (Fig. 1). Seed yield ha ${ }^{-1}$ was maximum $\left(1223 \mathrm{~kg} \mathrm{ha}^{-1}\right)$ from $100 \%$ of RDF $\left(\mathrm{N}_{2}\right)$ followed by $\mathrm{N}_{3}(125 \%$ of RDF). The lowest seed yield ha-1 $\left(924 \mathrm{~kg} \mathrm{ha}^{-1}\right)$ was recorded from $150 \%$ of RDF $\left(\mathrm{N}_{4}\right)$ followed by $\mathrm{N}_{1}$ (75\% of RDF). The highest seed yield from $100 \%$ of RDF $\left(\mathrm{N}_{2}\right)$ might be due to the higher number of capsules plant ${ }^{-1}$, number of seeds capsule ${ }^{-1}$, capsule length, and 1000 - seed weight. Jadhav et al. (1992) also reported that the highest grain yield was recorded when $120 \mathrm{~kg} \mathrm{~N}$ and $75 \mathrm{~kg} \mathrm{P}_{2} \mathrm{O}_{5} \mathrm{ha}^{-1}$ was applied on account of a higher number of capsules plant ${ }^{-1}$ and number of seeds capsule ${ }^{-1}$, which was statistically on par with $120 \mathrm{~kg} \mathrm{~N}$ and $50 \mathrm{~kg} \mathrm{P}_{2} \mathrm{O}_{5} \mathrm{ha}^{-1}$. Seed yield increased for every further increase in the rate of $\mathrm{N}$ and $\mathrm{K}$ application upto 80 and $60 \mathrm{~kg} \mathrm{ha}^{-1}$, respectively (Mandal et al., 1992). Nahar et al. (2008) indicated that the seed yield increased significantly up to $100 \mathrm{~kg} \mathrm{~N} \mathrm{ha}^{-1}$. Kathiresan (1999) indicated that the $\mathrm{P}$ level of $35 \mathrm{kgha}^{-1}$ influenced the seed yield of Sesamum. 

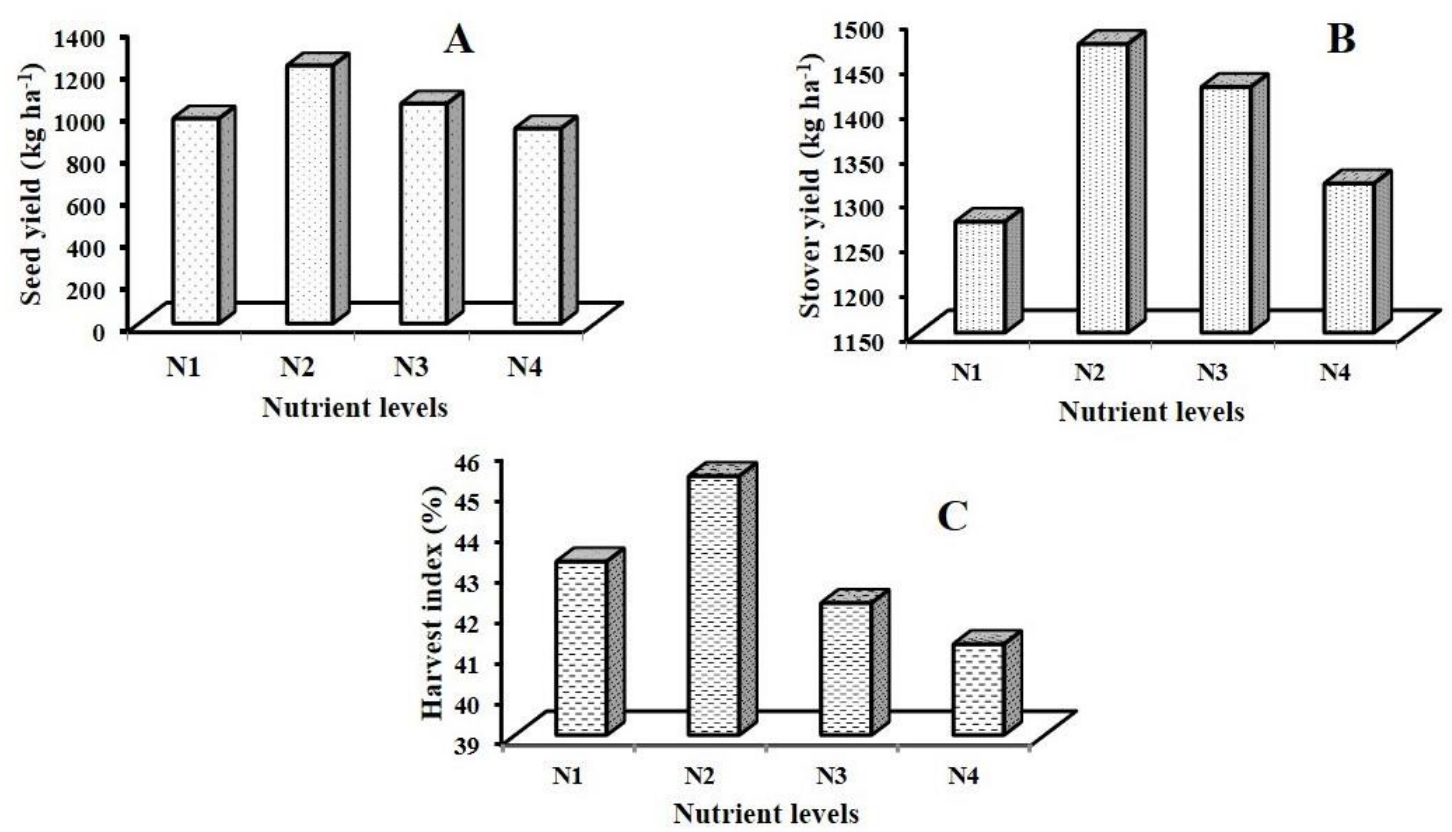

$\mathrm{N}_{1}=75 \%$ of RDF (43:54:23 kg N, $\mathrm{P}_{2} \mathrm{O}_{5}$ and $\left.\mathrm{K}_{2} \mathrm{O} \mathrm{ha}^{-1}\right), \mathrm{N}_{2}=100 \%$ of $\operatorname{RDF}\left(58: 72: 30 \mathrm{~kg} \mathrm{~N}, \mathrm{P}_{2} \mathrm{O}_{5}\right.$ and $\mathrm{K}_{2} \mathrm{O}$ ha $\left.^{-1}\right), \mathrm{N}_{3}=$ $125 \%$ of $\operatorname{RDF}\left(72: 90: 38 \mathrm{~kg} \mathrm{~N}, \mathrm{P}_{2} \mathrm{O}_{5}\right.$ and $\left.\mathrm{K}_{2} \mathrm{O} \mathrm{ha}^{-1}\right), \mathrm{N}_{4}=150 \%$ of $\mathrm{RDF}\left(86: 108: 45 \mathrm{~kg} \mathrm{~N}, \mathrm{P}_{2} \mathrm{O}_{5}\right.$ and $\left.\mathrm{K}_{2} \mathrm{O} \mathrm{ha}^{-1}\right)$

Fig.1. Seed yield (A), stover yield (B), and harvest index (C)of sesame as influenced by different levels of nutrients $\left(\mathrm{LSD}_{0.05}=13.43,16.45\right.$, and 0.679 , respectively)

The application of potassium markedly increased the seed yield (Mandal et al., 1992). Increasing the level of $\mathrm{K}$ from 100 to 150 percent of the recommended dose, the seed yield of sesame increased significantly (Subrahmaniyan et al., 2001). The stover yield ha ${ }^{-1}$ was highest $\left(1473 \mathrm{~kg} \mathrm{ha}^{-1}\right)$ from $100 \%$ of RDF $\left(\mathrm{N}_{2}\right)$ followed by $\mathrm{N}_{3}\left(125 \%\right.$ of RDF). The lowest stover yield ha-1 $\left(1274 \mathrm{~kg} \mathrm{ha}^{-1}\right)$ was recorded from $75 \%$ of RDF $\left(\mathrm{N}_{1}\right)$ which was followed by $\mathrm{N}_{4}$ (150\% of RDF). Ali and Jan (2014) reported that

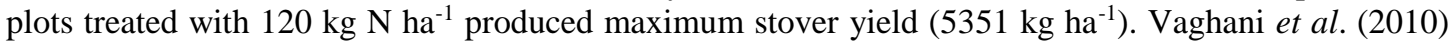
reported that significantly higher stover yields were achieved with the fertilizer application of $100 \mathrm{~kg} \mathrm{~N}$ $+25 \mathrm{~kg} \mathrm{P}_{2} \mathrm{O}_{5}+80 \mathrm{~kg} \mathrm{~K}_{2} \mathrm{O}+40 \mathrm{~kg} \mathrm{~S} \mathrm{ha}^{-1}$. Mian et al. (2011) opined that the highest seed and stover yield was recorded with $90 \mathrm{~kg} \mathrm{P}_{2} \mathrm{O}_{5} \mathrm{ha}^{-1}$. The harvest index was highest (45.36\%) from $100 \%$ of RDF $\left(\mathrm{N}_{2}\right)$ followed by $\mathrm{N}_{1}$ (75\% of RDF). The lowest harvest index (41.23\%) was recorded from $150 \%$ of RDF $\left(\mathrm{N}_{4}\right)$ which was statistically similar with $\mathrm{N}_{3}(125 \%$ of RDF). Ali and Jan (2014) reported that 120 $\mathrm{kg} \mathrm{N}$ ha ${ }^{-1}$ produced the highest harvest index. Khade et al. (1996) indicated that the harvest index increased with up to $50 \mathrm{~kg} \mathrm{P}_{2} \mathrm{O}_{5} \mathrm{ha}^{-1}$. The highest harvest index was achieved by the application of 44 $\mathrm{kg} \mathrm{N}$ and $44 \mathrm{~kg} \mathrm{P}_{2} \mathrm{O}_{5} \mathrm{ha}^{-1}$ (Abdel, 2008). Sarawagi et al. (1995) opined that significant seed yield, stover yield, and harvest index of summer sesame was 60 to $90 \mathrm{~kg} \mathrm{~K}_{2} \mathrm{O} \mathrm{ha}^{-1}$.

\section{Effect of varieties on yield and harvest index}

Significant influence was found for seed yield $\mathrm{ha}^{-1}$, stover yield ha $\mathrm{h}^{-1}$, and harvest index (\%) by different sesame varieties (Figure 2). The maximum seed yield ha-1 $\left(1170 \mathrm{~kg} \mathrm{ha}^{-1}\right)$ was obtained from $\mathrm{V}_{5}(\mathrm{BARI}$ Til-4) followed by $\mathrm{V}_{4}$ (BARI Til-3). The lowest seed yield ha ${ }^{-1}\left(811.30 \mathrm{~kg} \mathrm{ha}^{-1}\right)$ was observed from local variety $\mathrm{V}_{1}$ (Laltil) followed by local variety $\mathrm{V}_{2}$ (Atshira). Production capacity of yield contributing characters viz. number of capsules plant ${ }^{-1}$, number of seeds capsule ${ }^{-1}$, capsule length and weight of 1000- seeds was highest compared to other tested variety and resulted in highest seed yield. Suryabala et al. (2008) and Monpara et al. (2008) also found the yield of sesame varied significantly due to 
different varieties according to producing capability of yield contributing parameters. The maximum stover yield ha-1 (1476kg ha-1) was obtained from $\mathrm{V}_{5}$ (BARI Til-4) which was statistically similar with $\mathrm{V}_{4}$ (BARI Til-3) and $\mathrm{V}_{6}$ (Bina-til 2) followed by $\mathrm{V}_{3}(\mathrm{~T}-6)$. The lowest stover yield ha ${ }^{-1}\left(1139 \mathrm{~kg} \mathrm{ha}^{-1}\right)$ was observed from local variety $\mathrm{V}_{1}$ (Laltil) followed by local variety $\mathrm{V}_{2}$ (Atshira). Suryabala et al. (2008) and Hamdollah et al. (2009) opined that different Sesamum cultivars showed a significant variation in stover yield.
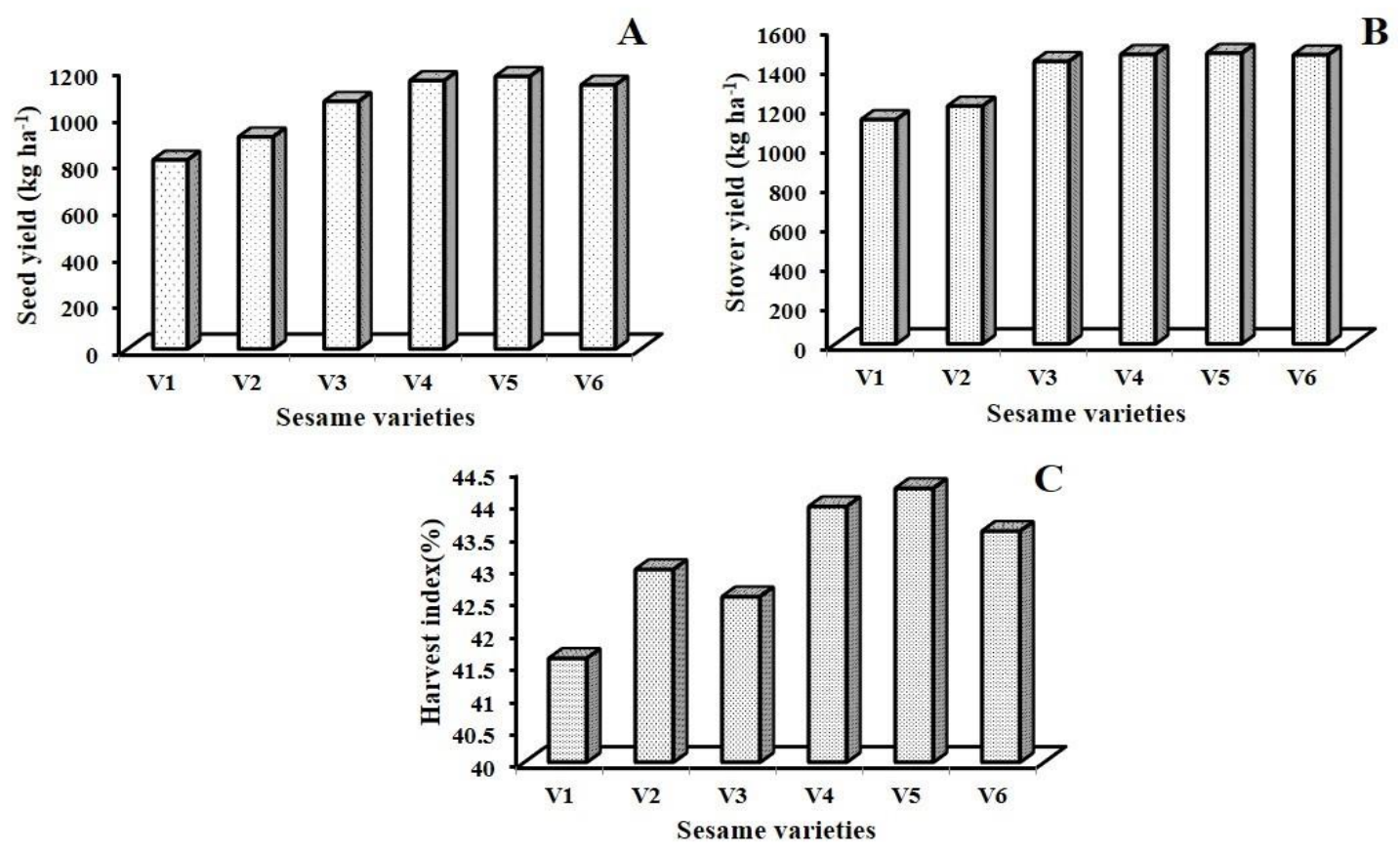

$\mathrm{V}_{1}=$ Laltil (Local), $\mathrm{V}_{2}=$ Atshira $\left(\right.$ Local), $\mathrm{V}_{3}=\mathrm{T}-6, \mathrm{~V}_{4}=$ BARI Til-3, $\mathrm{V}_{5}=$ BARI Til-4, $\mathrm{V}_{6}=$ BINAtil 2

Fig. 2. Seed yield (A), stover yield (B), and harvest index (C) of sesame as influenced by different varieties $\left(\mathrm{LSD}_{0.05}=16.44,14.82\right.$, and 0.713 , respectively)

The maximum harvest index (44.22\%) was obtained from $\mathrm{V}_{5}$ (BARI Til-4) which was statistically similar toV $\mathrm{V}_{4}$ (BARI Til-3). The lowest harvest index (41.60\%) was observed from local variety $\mathrm{V}_{1}$ (Laltil) followed by local variety $\mathrm{V}_{2}$ (Atshira). A similar result was also found by Balasubramaniyan et al. (1995) and they opined that different varieties had a significant effect on the harvest index. They also opined that HYV possesses a higher harvest index than the local variety. Ali and Jan (2014) also found significant variation with sesame varieties on seed yield, stover yield, and harvest index.

\section{Interaction effect of nutrient levels and varieties on yield and harvest index}

Statistically, significant variation was observed by the combined effect of different nutrients and varieties regarding seed yield ha $\mathrm{h}^{-1}$, stover yield $\mathrm{ha}^{-1}$, and harvest index (\%) (Table 3).Results signified that combination between different nutrient levels and varieties, $\mathrm{N}_{2} \mathrm{~V}_{5}$ listed the maximum seed yield $\mathrm{ha}^{-1}\left(1481 \mathrm{~kg} \mathrm{ha}^{-1}\right)$ which was statistically similar with $\mathrm{N}_{2} \mathrm{~V}_{4}$ followed by $\mathrm{N}_{2} \mathrm{~V}_{6}$. The lowest seed yield ha $^{-1}$ was recorded from $\mathrm{N}_{4} \mathrm{~V}_{1}\left(670 \mathrm{~kg} \mathrm{ha}^{-1}\right)$ which was followed by $\mathrm{N}_{4} \mathrm{~V}_{2}$. The maximum stover yield ha${ }^{1}\left(1715 \mathrm{~kg} \mathrm{ha}^{-1}\right)$ resulted in $\mathrm{N}_{2} \mathrm{~V}_{5}$ which was statistically similar with $\mathrm{N}_{2} \mathrm{~V}_{4}$ followed by $\mathrm{N}_{2} \mathrm{~V}_{6}, \mathrm{~N}_{2} \mathrm{~V}_{3}$, and $\mathrm{N}_{3} \mathrm{~V}_{5}$. The lowest stover yield ha' $\mathrm{a}^{-1}$ was recorded from $\mathrm{N}_{4} \mathrm{~V}_{1}\left(1043 \mathrm{~kg} \mathrm{ha}^{-1}\right)$ which was followed by $\mathrm{N}_{4} \mathrm{~V}_{2}$ and $\mathrm{N}_{3} \mathrm{~V}_{1}$. Finally, $\mathrm{N}_{2} \mathrm{~V}_{5}$ showed thatthe maximum harvest index (46.34\%) followed by $\mathrm{N}_{2} \mathrm{~V}_{6}$ and $\mathrm{N}_{2} \mathrm{~V}_{4}$. The lowest harvest index was recorded from $\mathrm{N}_{4} \mathrm{~V}_{2}$ (35.87\%) followed by $\mathrm{N}_{4} \mathrm{~V}_{1}$ and $\mathrm{N}_{4} \mathrm{~V}_{5}$. Bhosaleet al. 
(2011) found that sesame cv. 'GujratTil 2' reported significantly highest seed yield, stover yield, harvest index with the fertilizer application of $25 \mathrm{~kg} \mathrm{~N}+25 \mathrm{~kg} \mathrm{P}_{2} \mathrm{O}_{5}+50 \mathrm{~kg} \mathrm{~K}_{2} \mathrm{O} \mathrm{ha}{ }^{-1}$.

Table 3. Combined effect of different levels of nutrients and varieties on yield and harvest index of sesame

\begin{tabular}{cccc}
\hline Treatment & Seed yield ha $\mathbf{~ h}^{\mathbf{1}}(\mathbf{k g})$ & Stover yield ha $\left.^{-\mathbf{1}} \mathbf{( k g}\right)$ & Harvest index (\%) \\
\hline $\mathrm{N}_{1} \mathrm{~V}_{1}$ & $908.00 \mathrm{i}$ & $1203.00 \mathrm{jk}$ & $42.85 \mathrm{bcde}$ \\
$\mathrm{N}_{1} \mathrm{~V}_{2}$ & $965.30 \mathrm{~h}$ & $1247.00 \mathrm{ij}$ & $42.66 \mathrm{cde}$ \\
$\mathrm{N}_{1} \mathrm{~V}_{3}$ & $974.70 \mathrm{gh}$ & $1280.00 \mathrm{ij}$ & $44.42 \mathrm{a}$ \\
$\mathrm{N}_{1} \mathrm{~V}_{4}$ & $990.70 \mathrm{fgh}$ & $1317.00 \mathrm{gh}$ & $41.76 \mathrm{f}$ \\
$\mathrm{N}_{1} \mathrm{~V}_{5}$ & $1005.00 \mathrm{fg}$ & $1343.00 \mathrm{~g}$ & $40.22 \mathrm{~g}$ \\
$\mathrm{~N}_{1} \mathrm{~V}_{6}$ & $984.00 \mathrm{gh}$ & $1286.00 \mathrm{hi}$ & $41.62 \mathrm{f}$ \\
$\mathrm{N}_{2} \mathrm{~V}_{1}$ & $868.00 \mathrm{j}$ & $1182.00 \mathrm{k}$ & $39.52 \mathrm{gh}$ \\
$\mathrm{N}_{2} \mathrm{~V}_{2}$ & $961.30 \mathrm{~h}$ & $1239.00 \mathrm{j}$ & $43.53 \mathrm{bc}$ \\
$\mathrm{N}_{2} \mathrm{~V}_{3}$ & $1161.00 \mathrm{c}$ & $1622.00 \mathrm{c}$ & $42.10 \mathrm{def}$ \\
$\mathrm{N}_{2} \mathrm{~V}_{4}$ & $1457.00 \mathrm{a}$ & $1706.00 \mathrm{~b}$ & $43.18 \mathrm{bc}$ \\
$\mathrm{N}_{2} \mathrm{~V}_{5}$ & $1481.00 \mathrm{a}$ & $1715.00 \mathrm{a}$ & $36.34 \mathrm{j}$ \\
$\mathrm{N}_{2} \mathrm{~V}_{6}$ & $1408.00 \mathrm{~b}$ & $1664.00 \mathrm{c}$ & $42.11 \mathrm{def}$ \\
$\mathrm{N}_{3} \mathrm{~V}_{1}$ & $798.70 \mathrm{k}$ & $1128.00 \mathrm{l}$ & $38.91 \mathrm{hi}$ \\
$\mathrm{N}_{3} \mathrm{~V}_{2}$ & $958.70 \mathrm{~h}$ & $1238.00 \mathrm{j}$ & $43.62 \mathrm{~b}$ \\
$\mathrm{~N}_{3} \mathrm{~V}_{3}$ & $1105.00 \mathrm{~d}$ & $1512.00 \mathrm{~d}$ & $42.17 \mathrm{def}$ \\
$\mathrm{N}_{3} \mathrm{~V}_{4}$ & $1132.00 \mathrm{~cd}$ & $1530.00 \mathrm{~d}$ & $41.42 \mathrm{f}$ \\
$\mathrm{N}_{3} \mathrm{~V}_{5}$ & $1135.00 \mathrm{~cd}$ & $1621.00 \mathrm{c}$ & $38.15 \mathrm{i}$ \\
$\mathrm{N}_{3} \mathrm{~V}_{6}$ & $1120.00 \mathrm{~d}$ & $1519.00 \mathrm{~d}$ & $40.32 \mathrm{~g}$ \\
$\mathrm{~N}_{4} \mathrm{~V}_{1}$ & $670.70 \mathrm{~m}$ & $1043.00 \mathrm{~m}$ & $36.92 \mathrm{j}$ \\
$\mathrm{N}_{4} \mathrm{~V}_{2}$ & $756.00 \mathrm{l}$ & $1106.00 \mathrm{l}$ & $35.87 \mathrm{k}$ \\
$\mathrm{N}_{4} \mathrm{~V}_{3}$ & $1011.0 \mathrm{fg}$ & $1356.00 \mathrm{~g}$ & $42.98 \mathrm{bcd}$ \\
$\mathrm{N}_{4} \mathrm{~V}_{4}$ & $1027.00 \mathrm{ef}$ & $1468.00 \mathrm{ef}$ & $39.61 \mathrm{gh}$ \\
$\mathrm{N}_{4} \mathrm{~V}_{5}$ & $1059.00 \mathrm{e}$ & $1489.00 \mathrm{de}$ & $39.18 \mathrm{~h}$ \\
$\mathrm{~N}_{4} \mathrm{~V}_{6}$ & $1021.00 \mathrm{f}$ & $1438.00 \mathrm{f}$ & $42.03 \mathrm{ef}$ \\
\hline $\mathrm{LSD}_{0.05}$ & 33.22 & 41.16 & 0.7933 \\
\hline
\end{tabular}

In a column means having similar letter(s) are statistically similar and those having dissimilar letter(s) differ significantly at 0.05 level of probability.

Note: $\mathrm{N}_{1}=75 \%$ of RDF (43:54:23 kg N, P2O5 and K2O ha $\left.{ }^{-1}\right), \mathrm{N}_{2}=100 \%$ of RDF (58:72:30 kg N, P2O5 and $\mathrm{K}_{2} \mathrm{O}$ ha -1$)$, $\mathrm{N}_{3}=125 \%$ of $\operatorname{RDF}\left(72: 90: 38 \mathrm{~kg} \mathrm{~N}, \mathrm{P}_{2} \mathrm{O}_{5}\right.$ and $\mathrm{K}_{2} \mathrm{O}$ ha $\left.^{-1}\right), \mathrm{N}_{4}=150 \%$ of RDF (86:108:45 kg N, $\mathrm{P}_{2} \mathrm{O}_{5}$ and $\left.\mathrm{K}_{2} \mathrm{O} \mathrm{ha}^{-1}\right) ; \mathrm{V}_{1}=$ Laltil (Local), $\mathrm{V}_{2}=$ Atshira (Local), $\mathrm{V}_{3}=\mathrm{T}-6, \mathrm{~V} 4=$ BARI Til-3, $\mathrm{V}_{5}=$ BARI Til-4, $\mathrm{V}_{6}=$ Binatil 2

\section{Conclusion}

The combined effect of nutrient levels, $100 \%$ of RDF (58 -72- $30 \mathrm{Kg} \mathrm{N} \mathrm{P}_{2} 0_{5} \mathrm{~K}_{2} \mathrm{O} /$ ha) with variety. BARI til-4produced the highest seed yield $\left(1481 \mathrm{~kg} \mathrm{ha}^{-1}\right)$ and oil yield $\left(670 \mathrm{~kg} \mathrm{ha}^{-1}\right)$. .Hence, it is concluded that the combination of $100 \%$ of RDF and var. BARI Til-4is conductive to produce maximum seed yield $\left(\mathrm{kg} \mathrm{ha}^{-1}\right)$ of sesame in Bangladesh.

\section{References}

Abdel, R.A.E. 2008. Response of sesame to nitrogen and phosphorus fertilization in Northern Sudan. J. Appl. Biosci. 8(2): 304-308.

Balasubramaniyan, P., P. Gnanamurthy and V. Dharmalingam. 1995. Response oj irrigated sesame varieties to planting density and nitrogen. Sesame Safflower Newsl. 10: 59-62.

BARC (Bangladesh Agricultural Research Council). 2012. Fertilizer Recommended Guide, 2013. Farmgate, Dhaka, Bangladesh. 
BARI (Bangladesh Agricultural Research Institute). 2013. KrishiProjuktiHatboi (in Bengali). Bangladesh Agricultural Research Institute, Gazipur, Bangladesh. pp. 215-225.

BBS (Bangladesh Bureau of Statistics). 1996. Statistical Yearbook of Bangladesh. Bureau of Statistics, Statistics Division, Ministry of Planning, Govt, of the People's Republic of Bangladesh. Dhaka.

BBS (Bangladesh Bureau of Statistics). 2010. Statistical Yearbook of Bangladesh. Bureau of Statistics, Statistics Division, Ministry of Planning, Govt, of the People's Republic of Bangladesh. Dhaka.

BBS (Bangladesh Bureau of Statistics). 2020. Statistical Yearbook of Bangladesh. Bureau of Statistics, Statistics Division, Ministry of Planning, Govt, of the People's Republic of Bangladesh. Dhaka. p.121.

Bedigian, D., D. S. Seigler and J. R. Harlan. 1985. Sesamin, sesamolin and the original of sesame biochem systematics. Biochem. Syst. Ecol. 13(2):133-139.

Bennett, M.R.,K. Thiagalingam and D.F. Beeck. 1996. Effect of nitrogen application on growth, leaf nitrogen content, seed yield and yield components of sesame. Sesame Safflower Newsl.11: 21-28.

Bhosale, N. D., B. M. Dabhi, V. P. Gaikwad and T. C. Poonia. 2011. Response of Sesamum (Sesamumindicum L.) to different levels of potash and sulphur under south Saurashtra region. Advance Res. J. Crop Impr. 2(1): 121-124.

Chongdar, S., B. Chhetri, S.K. Mahato and A. Saha. 2015. Production potentials and economic feasibility of improved sesame (Sesamumindicum L.) cultivars under varying dates of sowing in prevailing agroclimatic condition of north bengal. Int. J. Agric. Sci. 7(2): 434-439.

Deshmukh, M.R., H.C. Jasin and S.S. Duhoon. 2005. Relative performance of sesame (Sesamumindicum L.) varieties in Kymore plateau zone of Madhya Pradesh (India). J. Oilseeds Res. 22(1): 197-198.

El-Serogy, S.T., M.A. El-Emam and W.A.I. Sorour. 1997. The performance of two sesame varieties under difference sowing methods in two locations. Ann. Agric. Sci. 42(2): 355-364.

Ghosh, D.C. and A.K. Patra. 1994. Effect of plant density and fertility levels on productivity and economics of summer sesame (Sesamumindicum L.). Indian J. Agron.39(1):71-75.

Gomez, K.A. and A.A. Gomez. 1984. Statistical procedures for agricultural research. John Wiley and Sons, New York.

Govindaraju, P.K. and Balakrishnan. 2002. Effect of soil alkalinity on plant growth, yield and oil content of sesamum. Madras Agric. J.89(1-3): 133-135.

Hamdollah E., Z.S. Saeid, G.G. Kazem and H.G. Mohammad. 2009. Effects of water limitation on grain and oil yields of sesame cultivars. J. Food Agric. Environ. 7(2): 339-342.

Jadhav, A.S., G.V. Chavan and S.R. Gungarde. 1992. Geometry of sesame (Sesamumindicum L.) cultivars under rainfed conditions. Indian J. Agron. 37(4): 857- 858.

Jebaraj, S. and M.N. Sheriff. 1996. SVPR 1 (TSS 6): A short duration high yielding white-seeded sesame for Tamil Nadu. Indian Fmg. 45(10): 5.

Kathiresan, G. 1999. Effect of growth regulators and clipping on sesame growth and yield in different seasons. Sesame Safflower Newsl. 14: 46-49.

Khade, V.N., S.N. Jadhav and S.A. Khanvilkar. 1996. Studies on scheduling of irrigation and phosphate fertilization to sesamum. J. Maharashtra Agric. Univ. 21(3): 410-411.

Khanam, M., M.S. Islam, M.H Ali., I.F. Chowdhury and S.M. Masum. 2016. Performance of soybean under different levels of phosphorus and potassium. Bangladesh Agron. J.19: 99-108.

Kokilavani, S., R. Jagannathan and S.K. Natarajan. 2007. Manual terminal clipping on yield and nutrient uptake of sesame varieties. Res. J. Agric. Biol. Sci.3(6): 987-999.

Lakshmi, P. and P. Lakshmamma 2005. Growth and yield of sesame (Sesamumindicum) as influenced by seasons. J. Oilseeds Res.22(1):228-230.

Mandal, S.S., D. Verma and S. Kuila. 1992. Effect of organic and inorganic sources of nutrients on growth and seed yield of sesame (Sesamumindicum L.). Indian J. Agric. Sci.62(4): 258-262.

Mian, M.A.K., M.K. Uddin, M.R. Islam, N.A. Sultana and H. Kohinoor. 2011. Crop performance and 
estimation of the effective level of phosphorus in sesame (Sesamumindicum L.). Academic J. Plant Sci. 4(1): 1-5.

Monayem, M.A., A. Sadia, M.A. Rashid and S.A.M. Shiblee. 2015. Factors affecting adoption of improved sesame technologies in some selected areas in Bangladesh: An empirical study. The Agriculturists. 13(1): 140-151.

Monpara, B.A., M.D. Vora, B.M. Chovatiya and B.V. Radadia. 2008. G. Til3: A white and bold seeded sesame (Sesamumindicum L.) variety for Saurashtra region of Gujarat. J. Oilseeds Res.25(2): 186187.

Myint D., A. Syed, Gilani, M. Kawase and K.N. Watanabe. 2020. Sustainable sesame (Sesamumindicum L.) production through improved technology: An overview of production, challenges, and opportunities in Myanmar. Sustainability. 12: 3515. doi:10.3390/su12093515

Nahar, Z., K.K. Mistry, A.K. Saha and Q.A. Khaliq. 2008. Response of nitrogen levels on yield of sesame (Sesamumindicum L.). SAARC J. Agri.6(1): 1-7.

Prakash, O.M., B.P. Singh and P.K. Singh. 2001. Effect of weed control measures and nitrogen fertilization on yield and yield attributes of sesamum(Sesamumindicum L.) under rainfed condition. Indian J. Agric. Sci.71(9): 610-612.

Prakasha, N.D. and S. Thimmegowda. 1992. Effect of irrigation and fertilizer levels on nutrient concentrations and protein yield of sesame (Sesamumindicum L.). Indian J. Agron.37(2): 387-388.

Raikwar, R.S. and P. Srivastva. 2013. Productivity enhancement of sesame (Sesamumindicum L.) through improved production technologies. African J. Agric. Res. 8(47): 6073-6078.

Raja, A., K.O. Hattab, L., Gurusamy and S.Suganya 2007. Sulphur levels on nutrient uptake and yield of sesame varieties and nutrient availability. Int. J. Soil Sci. 2: 278-285.

Rao, K.L., D.V.N. Raju and C.P. Rao. 1990. Response of sesamum varieties to rate and method of nitrogen application under rainfed condition. The Andhra Agric. J.37(2): 352-356.

Riaz A., M. Tariq, S.M. Farrukh and A. Shamim. 2002. Comparative performance of two sesamum (Sesamumindicum L.) varieties under different row spacings. Asian J. Plant Sci.1(5): 546-547.

Sarawagi, S.K., N. Lai, R.S. Tripathi and K.K. Purohit. 1995. Effect of nitrogen, potassium, sulphur on growth and yield of sesame in summer season. Ann. Agric. Res. 16(1): 101-103.

Subrahmaniyan, K., D. Dinakaran, P. Kalaiselven and N. Arulmozhi. 2001. Response of root rot resistant cultures of sesame (Sesamumindicum L.) to plant density and NPK fertilizer. Agric. Sci. Dig. 21(3): 176-178.

Suryabala Y., A.B. Abidi, R.P. Singh and A. Singh. 2008. Response of sulphur nutrition on nutritional characteristics of oil and cake of sesame (Sesamumindicum L.) varieties. J. Oilseeds Res. 25(1): 3840.

Tiwari, K.P., R.K. Jain and R.S. Raghuwanshi.1994. Effect of sowing dates and plant densities on seed yield of sesame cultivars. Crops Res. (Hisar). 8(2): 404-406.

Tripathy, S.K., J. Kar and D. Sahu. 2019. Advances in Sesame (Sesamumindicum L.) Breeding. In Advances in Plant Breeding Strategies: Industrial and Food Crops. Eds. Al-Khayri, J.M., S.M. Jain and D.V. Johnson. Springer, Cham, Switzerland. pp. 577-635.

Vaghani, J.J., K.B. Polara, P.K. Chovatia, B.V. Thumar and K.B. Parmar. 2010. Effect of nitrogen, potassium and sulphur on yield, quality and yield attributes of Kharif sesame (Sesamumindicum L.). Asian J. Soil Sci. 5(2): 318-321.

Yadav, L.N., A.K. Keshurwani, B.K. Verma and Y.D. Tiwari. 1991. September sown sesamum gives high yields in Madhya Pradesh. Indian Fmg. 41: 34-35.

Ali, S. and A. Jan. 2014. Sowing dates and nitrogen level effect on yield and yield attributes of sesame cultivars. Peshawar, Pakistan: Agricultural University Peshawar. Sarhad J. Agric. 30(2): 203-209. 